\title{
Panduan Mengidentifikasi Anak Berkebutuhan Khusus di Sekolah Inklusi
}

\author{
Debby Ashari ${ }^{1 凶}$ \\ Pendidikan Anak Usia Dini, Universitas Negeri Jakarta, Indonesia(1) \\ DOI: $10.31004 /$ obsesi.v6i2.1677
}

\begin{abstract}
Abstrak
Guru mengalami kesulitan dalam mengidentifikasi awal anak berkebutuhan khusus yang ada di sekolah inklusi. Penelitian ini bertujuan untuk mengembangkan panduan identifikasi anak berkebutuhan khusus di sekolah inklusi. Metode yang digunakan adalah dengan pendekatan penelitian dan pengembangan. Sampel penelitian ini adalah para guru yang mengajar di lembaga Taman Kanak-kanak yang bertugas di provinsi DKI Jakarta dengan jumlah guru 51 orang. Penelitian ini menghasilkan sebuah produk berupa panduan mengidentifikasi anak berkebutuhan khusus. Kebaruan penelitian ini adalah dihasilkannya panduan yang mengelaborasi model pengembangan Analyze, Design, Development, Implementation, dan Evaluation dengan model Rowentree yang telah teruji. Dampak dihasilkannya panduan ini adalah adanya tahapan perencanaan, persiapan, serta tahapan penulisan dan penyuntingan yang dapat memudahkan para guru dalam mengidentifikasi anak berkebutuhan khusus di sekolah. Pengembangan produk panduan ini perlu terus dilakukan di lapangan dan dikembangkan agar lebih teruji lagi.
\end{abstract}

Kata Kunci: anak berkebutuhan khusus; identifikasi; panduan; sekolah inklusi.

\begin{abstract}
This research is motivated by the difficulties of teachers in early identification of children with special needs in inclusive schools. This study aims to develop a guide to the identification of children with special needs in inclusive schools. The method used is a research and development approach. The sample of this research is the teachers who teach in Kindergarten institutions on duty in DKI Jakarta province with a total of 51 teachers. This research produces a product in the form of a guide to identify children with special needs. The novelty of this research is the production of a guide that elaborates the Analyze, Design, Development, Implementation, and Evaluation development model with the proven Rowentree model. The impact of this guide is that there are stages of planning, preparation, as well as stages of writing and editing that can make it easier for teachers to identify children with special needs in schools. The development of this guide product needs to be carried out in the field and developed to be more tested.
\end{abstract}

Keywords: children with special needs; identification; guidelines; inclusive schools.

Copyright (c) 2021 Debby Ashari

$\triangle$ Corresponding author :

Email Address : asharidebby@gmail.com (Jakarta, Indonesia)

Received 23 March 2021, Accepted 4 Auguts 2021, Published 07 August 2021 


\section{PENDAHULUAN}

Masa usia dini dapat menjadi sebuah permulaan atau awal dari sebuah pendidikan. Pendidikan pada masa Taman Kanak-kanak dirasa sangat penting karena dapat menjadi fondasi keberlangsungan pendidikan pada usia-usia selanjutnya. Pendidikan di masa Taman Kanak-kanak ini pun merupakan jenjang cikal bakal terbentuknya karakter seorang anak. Seorang anak dapat tumbuh dan berkembang dengan baik dan optimal jika mendapatkan berbagai stimulus yang tepat serta pengasuhan yang positif dari lingkungan sekitarnya (Hussain Alom Assistant Professor of Education, 2020).

Setiap anak di masa Taman Kanak-kanak diharapkan mendapatkan pendidikan serta stimulus yang tepat untuk mengoptimalkan perkembangan dan kemampuannya dimasa depan. Sigmund Freud menyatakan bahwa "In determining the basic need of the early child according to Freud was a necessity to accomplish, in order to allow the child achieve to his fullest" (Mensah \& Badu-Shayar, 2016). Pernyataan tersebut menyatakan bahwa untuk memaksimalkan potensi anak adalah dengan memenuhi kebutuhan dasar yang memang benar-benar butuh dikembangkan oleh anak.

Pendidikan dibutuhkan bukan hanya untuk anak-anak di usia Taman Kanak-kanak pada umumnya saja, namun juga bagi anak-anak yang memiliki kebutuhan khusus. Anakanak berkebutuhan khusus tersebut berhak diberikan pendidikan maupun stimulasi untuk lebih mengoptimalkan keterbatasan dan kelebihan yang mereka miliki. Banyak diantara anakanak berkebutuhan khusus tersebut yang mengalami kesulitan dalam memperoleh pembelajaran yang sesuai dengan kebutuhan di sekolah, bahkan menjadikan pembelajaran di kelas tidak optimal (Witarsa \& Dista, 2019).

Faktanya, pendidikan bagi anak berkebutuhan khusus lebih banyak diselenggarakan secara segregasi di Sekolah Luar Biasa (SLB) atau Taman Kanak-Kanak Luar Biasa (TK-LB). Namun yang terjadi saat ini adalah jumlah dan lokasi SLB atau TK-LB tersebut masih sangat terbatas. Hal ini pun mendorong munculnya pendidikan inklusi. Pendidikan inklusif juga merupakan strategi peningkatan mutu, karena model pembelajaran inklusif menggunakan metode pembelajaran bervariasi yang bisa menyentuh pada semua anak dan menghargai perbedaan (Jaya et al., 2018).

Seiring berjalannya waktu, penyelenggaraan sekolah inklusi pun telah menghadapi berbagai tantangan, baik yang berasal dari dalam maupun dari luar sekolah. Tantangan yang berasal dari dalam sekolah diantaranya adalah ketidaksiapan guru dalam mendidik anak berkebutuhan khusus di kelas inklusi tersebut (Pratiwi, J., 2015). Para guru masih kesulitan dalam melihat perbedaan atau mengidentifikasi antara anak-anak umum dengan anak-anak yang berkebutuhan khusus. Menanggapi berbagai tantangan di atas, diharapkan para guru memiliki kemampuan dalam mengidentifikasi juga mendeteksi serta memberikan intervensi yang sesuai dengan kebutuhan pembelajaran bagi masing-masing anak yang berkebutuhan khusus.

Peneliti mendapatkan data awal dari kuisioner yang telah divalidasi sebelumnya dan dilakukan kepada 51 orang partisipan yang seluruhnya berprofesi sebagai guru di tingkat Taman Kanak-Kanak. Datanya dapat dilihat pada Tabel. Pada Tabel 1 dapat dijelaskan bahwa sebanyak $98 \%$ para guru mengaku sudah mengetahui tentang "deteksi dini", kemudian sebanyak 52,9\% guru pernah mengikuti pelatihan seputar anak berkebutuhan khusus, lalu sebanyak $100 \%$ guru menyatakan bahwa sangat penting deteksi dini dilakukan bagi anak seawal mungkin. 92,2\% guru telah mengenal perilaku anak berkebutuhan khusus, kemudian sebanyak $86,3 \%$ guru mengaku pernah mengamati perilaku anak yang muncul dengan kebutuhan khusus. Terdapat $74,5 \%$ guru yang mengaku telah melakukan deteksi anak berkebutuhan khusus dalam pembelajaran di kelas. 72,5\% guru telah mengetahui aktifitas diferensiasi, kemudian sebanyak $76,5 \%$ guru mengaku pernah melakukan aktifitas diferensiasi pada saat pembelajaran di kelas. 94,1\% guru menyatakan bahwa aktifitas diferensiasi dapat mengoptimalkan pembelajaran di kelas dan terakhir, sebanyak $100 \%$ guru 
menyatakan bahwa perlu dikembangkan panduan tentang deteksi dini anak berkebutuhan khusus.

Tabel 1. Data Awal Kuisioner

\begin{tabular}{clc}
\hline No. & \multicolumn{1}{c}{ Indikator } & Persentase (\%) \\
\hline 1 & Guru mengaku sudah mengetahui tentang deteksi dini & 98 \\
2 & Guru pernah mengikuti pelatihan seputar anak berkebutuhan khusus & 52,9 \\
3 & $\begin{array}{l}\text { Guru menyatakan bahwa sangat penting deteksi dini dilakukan bagi anak } \\
\text { seawal mungkin }\end{array}$ & 100 \\
4 & $\begin{array}{l}\text { Guru telah mengenal perilaku anak berkebutuhan khusus } \\
5\end{array}$ & $\begin{array}{l}\text { Guru mengaku pernah mengamati perilaku anak yang muncul dengan } \\
\text { kebutuhan khusus }\end{array}$ \\
$6 \quad \begin{array}{l}\text { Guru mengaku telah melakukan deteksi anak berkebutuhan khusus dalam } \\
\text { pembelajaran di kelas }\end{array}$ & 86,3 \\
7 & $\begin{array}{l}\text { Guru telah mengetahui aktifitas diferensiasi } \\
8\end{array}$ & $\begin{array}{l}\text { Guru mengaku pernah melakukan aktifitas diferensiasi pada saat } \\
\text { pembelajaran di kelas }\end{array}$ \\
9 & $\begin{array}{l}\text { Guru menyatakan bahwa aktifitas diferensiasi dapat mengoptimalkan } \\
\text { pembelajaran di kelas }\end{array}$ & 72,5 \\
10 & $\begin{array}{l}\text { Guru menyatakan bahwa perlu dikembangkan panduan tentang deteksi } \\
\text { dini anak berkebutuhan khusus }\end{array}$ & 94,1 \\
\hline
\end{tabular}

Para guru partisipan dalam kuisioner awal ini berasal dari berbagai latar belakang pendidikan. Hasil kuisioner awal tersebut menunjukkan bahwa guru-guru membutuhkan acuan yang sederhana, jelas, dan mudah untuk ditelaah serta digunakan dalam memberikan identifikasi dan intervensi yang sesuai bagi kondisi setiap anak berkebutuhan khusus. Berdasarkan latar belakang masalah, identifikasi masalah, dan pembatasan masalah yang telah diungkapkan sebelumnya, maka perumusan masalah dalam penelitian ini adalah "Bagaimana mengembangkan panduan identifikasi anak berkebutuhan khusus yang tepat bagi guru Taman Kanak-kanak di provinsi DKI Jakarta?".

Penelitian ini secara teori mengacu juga pada teori-teori yang diungkapkan oleh para ahli sebelumnya. Suryaningrum et al. (2016) menyatakan bahwa buku panduan adalah sarana belajar yang digunakan di sekolah-sekolah dan di perguruan tinggi untuk menunjang suatu pengajaran dalam pengertian yang modern dan yang umum dipahami. (Pinandhita \& Christiana, 2016) juga mengungkapkan bahwa buku panduan merupakan buku yang disusun untuk bidang studi tertentu. Buku panduan mempunyai acuan berupa standar dan disusun oleh para pakar dalam bidangnya yang terdapat maksud untuk tujuan intruksional dan dilengkapi dengan sarana-sarana pengajaran yang mudah dipahami oleh pembacanya. Penyusunan buku dilakukan dengan acuan standar tertentu sehingga buku panduan dapat layak digunakan. Adapun kelebihan dari buku panduan yang dinyatakan oleh (Kurniazuhroh \& Adhe, 2019) yaitu bahwa buku panduan merupakan pegangan guru dalam menentukan metode pembelajaran dan dapat memberikan pengetahuan bagi penggunanya.

Buku panduan merupakan buku yang disusun untuk bidang studi tertentu, yang mempunyai acuan standar dan disusun oleh para pakar dalam bidangnya yang terdapat maksud untuk tujuan intruksional dan dilengkapi dengan sarana-sarana pengajaran yang sesuai dan mudah diimplementasikan oleh pemakainya. Buku panduan dapat dikatakan sebagai buku umum yang didalamnya terdapat buku pelajaran atau buku bacaan yang tergolong sebagai pemandu sehingga dapat disimpulkan bahwa buku panduan merupakan teks yang digunakan dan atau berfungsi sebagai pemandu.

Fungsi buku panduan menurut (Musanib, 2013), yaitu (1) mencerminkan sudut pandang yang tangguh dan modern mengenai pengajaran yang disajikan, (2) menyajikan suatu sumber pokok masalah atau subject matter yang kaya, mudah dibaca, dan bervariasi yang sesuai dengan minat dan kebutuhan, sebagai dasar bagi program-program kegiatan yang disarankan sehingga keterampilan-keterampilan ekspresional diperoleh dibawah 
kondisi-kondisi yang menyerupai kehidupan sebenarnya, (3) menyajikan suatu sumber yang tersusun rapi dan bertahap mengenai keterampilan ekspresional yang mengemban masalah pokok dalam komunikasi, (4) menyaksikan bersama-sama dengan buku manual yang mendampingi metode-metode dan sarana-sarana pengajaran untuk memotivasi, (5) menyajikan fiksasi (perasaan mendalam) awal yang perlu dan juga sebagai penunjang latihanlatihan dan tugas-tugas praktis, dan (6) menyajikan bahan atau sarana/evaluasi dan remedial yang serasi dan tepat guna.

Fungsi dari buku panduan adalah sebagai sumber pokok masalah yang dijadikan dasar bagi program kegiatan yang disarankan dan sebagai sumber bahan pembelajaran, menyegarkan ingatan, dan memotivasi belajar. (Jaya et al., 2018) memaparkan bahwa buku panduan pendidikan adalah buku yang memuat prinsip, prosedur, deskripsi materi pokok, atau model pembelajaran yang digunakan oleh para pendidik dalam menjalankan tugas pokok dan fungsi sebagai pendidik. Dalam pengertian yang lebih luas, buku panduan pendidikan adalah buku materi atau isinya dapat digunakan untuk meningkatkan kinerja pendidik dan/atau tenaga kependidikan.

Proses identifikasi merupakan hal yang sangat penting untuk dilakukan. Identifikasi adalah kegiatan awal yang mendahului proses asesmen. Menurut (Moeschler et al., 2014) menyatakan bahwa "Identifying the type of developmental delay is an important preliminary step, because typing influences the path of investigation later undertaken", yang mana menjelaskan bahwa sangat penting melakukan identifikasi dini pada keterlambatan perkembangan anak. Identifikasi dini merupakan langkah awal yang akan mempengaruhi jalur investigasi yang dilakukan kemudian.

Anggadewi, B., E. \& Evanjeli, L. (2019) dan (Hussain Alom Assistant Professor of Education, 2020) juga menungkapkan bahwa "Because of the importance of proactive early intervention for young children with behavioural challenges, researchers have described the need for the adoption of models or curriculum approaches for providing a continuum of evidence-based prevention and intervention practices that can address the social development and behavioural support needs of children within an early childhood programme". Dari pernyataan diatas nampak jelas bahwa intervensi dini proaktif untuk anak-anak berkebutuhan khusus sangat penting pada usia dini khususnya anak-anak dengan tantangan perilaku. Para peneliti telah menjelaskan perlunya adopsi model atau pendekatan kurikulum untuk menyediakan kontinum praktik pencegahan dan intervensi berbasis bukti yang dapat mengatasi perkembangan sosial dan dukungan perilaku sebagai pemenuhan kebutuhan anak-anak berkebutuhan khusus dalam program anak usia dini.

Hasil dari identifikasi dilanjutkan dengan asesmen, yang hasilnya akan dijadikan dasar untuk penyusunan progam pembelajaran sesuai dengan kemampuan dan ketidakmampuannya (Maman et al., 2021). Dalam penyelenggaraan pendidikan inklusif, kegiatan identifikasi anak berkebutuhan khusus dilakukan untuk lima keperluan, yaitu: (1) Penjaringan (screening), (2) Pengalihtanganan (referal), (3) Klasifikasi, (4) Perencanaan pembelajaran, dan (5) Pemantauan kemajuan belajar. (Anggadewi, B., E. \& Evanjeli, L., 2019) menyatakan bahwa "The results of the identification can be continued with an assessment where the overall results are used as the basis for the preparation of learning programs according to their abilities and disabilities". Dari pernyataan tersebut dapat disintesiskan bahwa hasil identifikasi dapat dilanjutkan dengan penilaian dimana hasil keseluruhan digunakan sebagai dasar penyusunan program pembelajaran sesuai dengan kemampuan dan jenis kecacatannya. Diharapkan hasil tersebut dapat membantu para guru dalam membuat rencana pembelajaran yang tentunya sesuai dengan kebutuhan masing-masing anak agar potensi yang dimiliki setiap anak dapat berkembang secara optimal.

Adapun harapan dan manfaat dari adanya panduan yang dihasilkan adalah adanya panduan yang berisi tahapan-tahapan perencanaan, persiapan, serta tahapan penulisan dan penyuntingan yang dapat memudahkan para guru Taman Kanak-kanak dalam mengidentifikasi anak berkebutuhan khusus di sekolah. 
Penelitian-penelitian sebelumnya menunjukkan adanya gap dan kekurangan dalam hal model pengembangan yang digunakan, sedangkan penelitian ini mengembangkan panduan yang mengelaborasi model pengembangan Analyze, Design, Development, Implementation, dan Evaluation dengan model Rowentree yang belum pernah dilakukan sebelumnya.

\section{METODOLOGI}

Penelitian dilakukan menggunakan pendekatan penelitian dan pengembangan atau biasa dikenal dengan istilah lainnya Research and Development (R\&D). Penelitian ini menghasilkan sebuah produk berupa panduan mengidentifikasi anak berkebutuhan khusus. Desain penelitian digambarkan sebagai berikut:

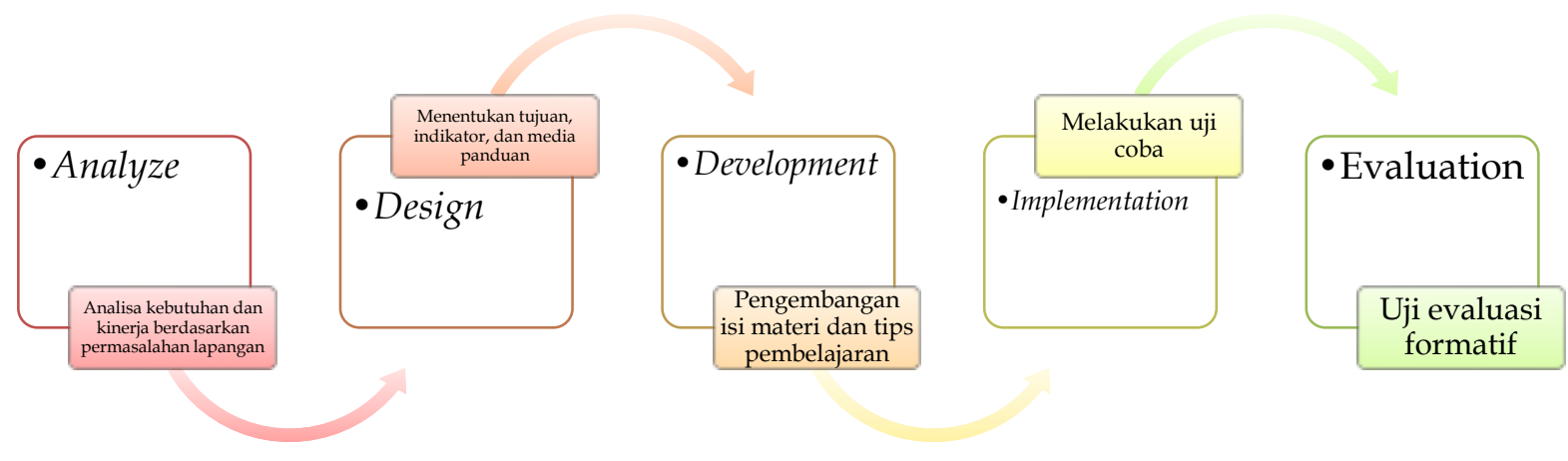

Gambar 1. Tahapan Pengembangan Produk Adaptasi dari Model ADDIE

(Roza \& Rifma, 2000)

Model pengembangan yang digunakan dalam penelitian dan pengembangan ini adalah model pengembangan ADDIE yang mana terdiri dari lima tahapan, yaitu 1) Analyze, melakukan analisa kebutuhan dan kinerja berdasarkan permasalahan lapangan; 2) Design, menentukan tujuan, indikator pencapaian serta perancangan bentuk media panduan; 3) Development, pengembangan isi materi dan tips kegiatan pembelajaran; 4) Implementation, melakukan uji coba; dan 5) Evaluation, melakukan evaluasi formatif. Model ADDIE ini pun terintegrasi dengan model Rowentree. Pengintegrasian kedua model yang merupakan model pengembangan yang berorientasi pada hasil produk, dan dalam hal ini adalah produk media cetak. Adapun langkah-langkah yang diterapkan terdiri dari 1) tahapan perencanaan, yang bertujuan untuk merumuskan tujuan dan menentukan media, 2) tahapan persiapan, yang bertujuan untuk menyusun garis besar materi, serta 3) tahapan penulisan dan penyuntingan, menyusun, menyunting dan uji coba draft awal. Model Rowentree setiap tahapannya memiliki sasaran yang bertujuan pada produksi bahan ajar.

Populasi penelitian ini adalah guru-guru TK di provinsi DKI Jakarta. Pada analisis kebutuhan sampai dengan akhir penelitian, yang menjadi sampel penelitian adalah para guru yang mengajar di lembaga Taman Kanak-Kanak usia 4-6 tahun yang bertugas di DKI Jakarta sebanyak 51 orang guru. Teknik pengumpulan data dilakukan secara kuantitatif dan kualitatif. Teknik penarikan kesimpulan dilakukan secara kualitatif berdasarkan hasil uji coba dan uji produk pada tahap akhir.

Rencana aspek penilaian dilakukan secara kuantitatif dan kualitatif. Instrumen yang digunakan untuk mengevaluasi panduan terdiri dari dua jenis instrumen, yaitu 1) instrumen untuk ahli materi yang divalidasi oleh Psikolog, 2) instrumen untuk ahli instrumen identifikasi anak berkebutuhan khusus oleh ahli Pendidikan Khusus. Pada tahapan ini ahli materi memberikan validasi terhadap isi/informasi yang terdapat dalam buku panduan yang dikembangkan. Kisi-kisi instrumen bisa dilihat pada Tabel-tabel berikut: 
Tabel 2. Kisi-Kisi Penilaian Ahli Instrumen

\begin{tabular}{lll}
\hline \multicolumn{1}{c}{ Aspek } & & \multicolumn{1}{c}{ Indikator } \\
\hline Bahasa & a. & Penggunaan bahasa dalam instrumen mudah dimengerti. \\
& b. & Penggunaan bahasa dalam instrumen efektif. \\
& c. & Kesesuaian bahasa dalam instrumen dengan kaidah bahasa Indonesia yang baik \\
& dan benar. \\
& d. & Struktur kalimat dalam instrumen memudahkan responden untuk memberikan \\
& & skor. \\
Konstruksi & a. Butir instrumen yang disusun mewakili aspek yang akan diukur. \\
& b. Kualitas pertanyaan butir instrumen yang disusun. \\
& c. Butir instrumen dapat menggambarkan respon yang diharapkan. \\
Materi & a. Butir instrumen yang disusun sesuai dengan teori. \\
& b. Kelengkapan materi pada butir instrumen. \\
& c. Kelayakan instrumen untuk digunakan. \\
\hline
\end{tabular}

Tabel 3. Kisi-Kisi Penilaian Ahli Materi Panduan

\begin{tabular}{lll}
\hline \multicolumn{1}{c}{ Aspek } & & \multicolumn{1}{c}{ Indikator } \\
\hline Tujuan & a. & Kesesuaian materi dengan tujuan. \\
Pembelajaran & b. Uraian penjelasan secara detail. \\
& c. Kesesuaian materi dengan kompentensi. \\
& a. Keakuratan informasi. \\
& b. Keruntutan penyajian materi. \\
& c. Materi memperluas wawasan. \\
& d. Materi mudah dipahami. \\
Bahasa & e. Aktifitas mudah dilakukan. \\
& a. Kesesuaian pemilihan kosa kata. \\
& b. Kejelasan petunjuk penggunaan. \\
& c. Kesantunan penggunaan bahasa. \\
& d. Ketepatan teks dengan materi. \\
\hline
\end{tabular}

Tabel 4. Kisi-Kisi Instrumen Penilaian Ahli Media

\begin{tabular}{lll}
\hline \multicolumn{1}{c}{ Aspek } & \multicolumn{1}{c}{ Indikator } \\
\hline Tampilan & a. & Kesesuaian gambar sampul depan dengan konten. \\
& b. Kesesuaian standard ukuran buku. \\
& c. Ketepatan pemilihan jenis kertas. \\
& d. Kerapihan susunan layout. \\
& e. Kemenarikan tampilan sampul depan. \\
Praktis & a. Mudah dipegang. \\
& b. Mudah dibawa. \\
Teks & a. Kesesuaian konten pembelajaran. \\
Tulisan & b. Keruntunan konten pembelajaran. \\
& c. Ketepatan jenis dan ukuran huruf. \\
Ilustrasi & d. Kemudahan membaca teks. \\
Gambar & a. Kualitas gambar. \\
& b. Ketepatan penempatan gambar. \\
& c. Kesesuaian gambar dengan materi. \\
\hline
\end{tabular}

Proses validasi dari evaluasi merupakan proses dalam menyediakan dan menggunakan informasi sebagai dasar dalam pengambilan keputusan guna memberikan peningkatan terhadap kualitas panduan identifikasi anak berkebutuhan khusus. Untuk mendapatkan data informasi dari para ahli maka digunakan instrumen angket dengan bentuk 
penilaian skala sikap. Penelitian dan pengembangan ini melibatkan responden yaitu para guru yang bertugas di sekolah TK, serta beberapa para ahli yaitu (1) ahli instrumen identifikasi anak berkebutuhan khusus, yang memberikan penilaian dan masukan pada instrumen identifikasi dini anak berkebutuhan khusus yang dikembangkan, (2) ahli materi dalam bidang Psikologi untuk memberikan penilaian mengenai ketepatan isi materi yang disajikan dalam produk panduan, serta (3) pengguna panduan identifikasi anak berkebutuhan khusus, yaitu para guru TK (usia 4-6 tahun).

Adapun evaluasi yang digunakan dalam pengembangan panduan identifikasi anak berkebutuhan khusus adalah evaluasi formatif. Evaluasi dilakukan ketika buku panduan diujicoba kepada pengguna yang bertujuan agar tahapan pengembangan panduan anak berkebutuhan khusus ini teruji di lapangan sehingga menjadi optimal dan tentunya mencapai tujuan yang diharapkan. Adapun kisi-kisi instrumen uji coba terhadap produk yang akan dikembangkan dapat dilihat dalam Tabel berikut:

Tabel 5. Kisi-Kisi Instrumen Penilaian Kuisioner Ujicoba

\begin{tabular}{|c|c|}
\hline Aspek & Indikator \\
\hline Pembelajaran & $\begin{array}{l}\text { a. Kesesuaian materi pembelajaran dengan kebutuhan guru. } \\
\text { b. Kemampuan materi dalam memotivasi guru untuk belajar. } \\
\text { c. Kesesuaian metode pembelajaran dengan kemampuan guru. } \\
\text { d. Kesesuaian contoh dengan isi materi. } \\
\text { e. Contoh mudah dimengerti oleh para guru. } \\
\text { f. Contoh memotivasi para guru untuk materi berikutnya. }\end{array}$ \\
\hline $\begin{array}{l}\text { Fungsi dan } \\
\text { ukuran buku }\end{array}$ & $\begin{array}{l}\text { a. Belajar dengan kecepatan sendiri. } \\
\text { b. Belajar dimanapun atau kapanpun. } \\
\text { c. Ukuran buku praktis. }\end{array}$ \\
\hline $\begin{array}{l}\text { Bahasa dan } \\
\text { struktur }\end{array}$ & $\begin{array}{l}\text { a. Bahasa yang digunakan mudah dipahami. } \\
\text { b. Bahasa yang digunakan memotivasi guru membaca. }\end{array}$ \\
\hline kalimat & $\begin{array}{l}\text { c. Penggunaan bahasa yang komuikatif. } \\
\text { d. Kemudahan dalam memahami makna kalimat. } \\
\text { e. Kejelasan tanda baca yang digunakan. }\end{array}$ \\
\hline Tata letak & $\begin{array}{l}\text { a. Kemenarikan tata letak sampul. } \\
\text { b. Penyajian tata letak isi memudahkan materi untuk dibaca. } \\
\text { c. Penyajian tata letak isi menarik. }\end{array}$ \\
\hline Ilustrasi & $\begin{array}{l}\text { a. Ilustrasi pada sampul menarik. } \\
\text { b. Ilustrasi pada isi buku menarik. }\end{array}$ \\
\hline Warna & $\begin{array}{l}\text { a. Komposisi warna pada sampul menarik. } \\
\text { b. Komposisi warna pada isi menarik. }\end{array}$ \\
\hline
\end{tabular}

Proses evaluasi ini sendiri dilakukan pada beberapa tahap dan melibatkan para ahli. Selain itu pada panduan identifikasi anak berkebutuhan khusus ini dilakukan proses evaluasi berupa uji coba one to one dan uji coba kelompok kecil. Pada tahapan ini akan dilakukan evaluasi berupa kualitatif mengenai panduan identifikasi anak berkebutuhan khusus.

Produk yang telah diujicoba serta diperbaiki sesuai dengan saran yang diperoleh selanjutnya diujicoba kembali kepada guru TK untuk menilai kelayakan penggunaan panduan identifikasi anak berkebutuhan. Kelayakan hasil produk yang dikembangkan berdasarkan evaluasi sikap guru TK terhadap penggunaan panduan identifikasi anak berkebutuhan khusus yang telah digunakan.

Data yang diperoleh dalam penelitian ini berupa data kualitatif dan kuantitatif. Data berbentuk komentar, saran, dan hasil wawancara dianalisis secara deskriptif kualitatif untuk menyusun dan memperbaiki produk yang dikembangkan. Deskriptif kualitatif digunakan untuk menganalisa data dengan cara mendeskripsikan atau menggambarkan data yang telah terkumpul sebagaimana adanya tanpa maksud membuat kesimpulan yang berlaku untuk umum. 
Dalam penelitian ini instrumen yang digunakan berupa angket. Data angket diperoleh berdasarkan hasil validasi ahli materi, ahli media, dan uji coba lapangan. Angket yang digunakan adalah skala likert, yaitu skala 4 dengan kriteria sebagai berikut: (Skor $4=$ Sangat Baik), (Skor 3 = Baik), (Skor 2 = Cukup), (Skor 1 = Kurang Baik).

\section{HASIL DAN PEMBAHASAN}

\section{Penelitian Pendahuluan}

Pada tahap analisis dilaksanakan dengan melakukan studi penelitian pendahuluan melalui studi lapangan berupa kegiatan survei pengetahuan dan keterampilan guru terkait proses identifikasi awal anak berkebutuhan khusus di usia dini serta studi literatur. Pada tahap ini peneliti melakukan beberapa kegiatan analisis yang dapat dijadikan sebagai bahan pertimbangan dalam menentukan media yang tepat tujuan dan sasaran. Hasil analisis studi literatur yang peneliti lakukan ditemukan bahwa setiap anak berhak untuk mendapatkan pendidikan maupun pembelajaran yang layak. Pada khususnya anak usia dini, dimana pada masa tersebut membutuhkan berbagai stimulasi guna mengoptimalkan seluruh aspek perkembangan. Hal ini sejalan juga dengan hasil penelitian yang diungkapkan oleh (Rapisa, 2018) bahwa untuk mengoptimalkan kemampuan guru dalam mengidentifikasi anak berkebutuhan khusus perlu dilakukan stimulasi dan pemantauan awal seluruh aspek perkembangan agar guru tidak salah dalam mengidentifikasi anak.

Dalam proses mengoptimalisasikan aspek perkembangan tersebut, seluruh anak usia dini membutuhkan pembelajaran yang sesuai dengan kemampuan maupun kebutuhan secara personal, tidak terkecuali pada anak usia dini yang berkebutuhan khusus. Anak usia dini harus segera diidentifikasi dan atau ditemukenali segala kemungkinan yang dapat menghambat perkembangannya. Semakin dini anak diidentifikasi, maka semakin ada kesempatan untuk dapat mengoptimalkan perkembangannya (Hafidh et al., 2020). Melalui observasi awal yang telah diungkapkan, peneliti menemukan data bahwa pada beberapa anak yang dinyatakan memiliki kebutuhan khusus di sekolah tersebut belum tertangani dengan optimal. Beberapa guru masih kesulitan dalam menemukenali kondisi, kemampuan serta kebutuhan anak tersebut. Pada anak-anak yang dinyatakan memiliki kebutuhan khusus di kelas, masih mendapatkan pembelajaran yang sama dengan teman-teman sekelas pada umumnya. Padahal, untuk anak berkebutuhan khusus itu sendiri perlu memiliki program pembelajaran individual yang tentunya telah dipersonalisasi sesuai dengan kemampuan serta kebutuhannya.

Dalam perancangan program pembelajaran individual itu sendiri, guru kelas memerlukan bantuan profesional dan tentunya keluarga anak berkebutuhan khusus serta seluruh lingkungan sekolah. Setelah proses analisis kebutuhan dan kinerja dalam pengembangan buku panduan selesai peneliti laksanakan, maka selanjutnya peneliti menentukan peta kebutuhan buku panduan sesuai dengan kompetensi guru yaitu pada pemetaan kompetensi guru dan memetakan materi panduan.

\section{Hasil Uji Kelayakan Pakar Pertama}

Ahli media menguji kelayakan atau memvalidasi draft satu buku panduan identifikasi awal anak berkebutuhan khusus di usia dini. Diperoleh hasil skor rata-rata penilaian pertama dalam bentuk prosentase sebesar $60,41 \%$. Hasil dari penilaian ini berada dalam kriteria interpretasi skor $51 \%-75 \%$ dinilai baik dengan makna yang menyatakan bahwa buku panduan identifikasi awal anak berkebutuhan khusus layak dan dapat digunakan sebagai media. Kemudian ahli materi menguji kelayakan atau memvalidasi draft satu buku panduan identifikasi awal anak berkebutuhan khusus di usia dini. Diperoleh skor rata-rata penilaian pertama dalam bentuk prosentase adalah $78,33 \%$. Hasil dari penilaian ini berada dalam kriteria interpretasi skor 76\%-100\% dinilai sangat baik dengan makna yang menyatakan bahwa buku panduan identifikasi awal anak berkebutuhan khusus layak dan dapat digunakan sebagai media. 
Pada ahli instrumen yang menguji kelayakan atau memvalidasi draft satu buku panduan identifikasi awal anak berkebutuhan khusus di usia dini didapatkan hasil penilaian ahli materi terhadap buku panduan identifikasi anak berkebutuhan khusus diperoleh skor rata-rata penilaian pertama dalam bentuk prosentase adalah $74,99 \%$. Hasil dari penilaian ini berada dalam kriteria interpretasi skor $51 \%-75 \%$ dinilai baik dengan makna yang menyatakan bahwa buku panduan identifikasi awal anak berkebutuhan khusus layak dan dapat digunakan sebagai media.

\section{Hasil Uji Coba (One to one)}

Tabel 6. Hasil Uji Coba (One to one)

\begin{tabular}{clcc}
\hline No. & \multicolumn{1}{c}{ Aspek } & Skor Perolehan & Skor Maksimal \\
\hline 1. & Materi Panduan & 44 & 48 \\
2. & Bahasa dan Struktur Kalimat & 28 & 36 \\
3. & Tampilan Buku Panduan & 52 & 84 \\
& Total & 124 & 168 \\
& Rata-rata (\%) & & 73,80 \\
& Interpretasi & \multicolumn{2}{c}{ Baik } \\
\hline
\end{tabular}

Dari hasil penilaian guru melalui uji coba one to one ini diperoleh rata- rata sebesar $73,80 \%$ (tabel 6). Hasil penilaian ini masuk dalam kriteria baik. Hal ini dapat diinterpretasikan bahwa buku panduan identifikasi awal anak berkebutuhan khusus diusia dini telah layak digunakan.

\section{Hasil Uji Coba Kelompok Kecil}

Tabel 7. Hasil Uji Coba Kelompok Kecil

\begin{tabular}{clcc}
\hline No. & \multicolumn{1}{c}{ Aspek } & Skor Perolehan & Skor Maksimal \\
\hline 1. & Materi Panduan & 74 & 80 \\
2. & Bahasa dan Struktur Kalimat & 46 & 60 \\
3. & Tampilan Buku Panduan & 94 & 140 \\
& Total & 214 & 280 \\
& Rata-rata (\%) & \multicolumn{2}{c}{76,42} \\
\multicolumn{2}{c}{ Interpretasi } & \multicolumn{2}{c}{ Sangat Baik } \\
\hline
\end{tabular}

Dari hasil penilaian guru melalui uji coba small group ini diperoleh rata- rata $76,42 \%$ (tabel 7). Hasil penilaian ini masuk dalam kriteria sangat baik. Hal ini dapat diinterpretasikan bahwa sangat layak digunakan.

\section{Uji Coba Lapangan Utama}

Uji coba lapangan utama bertujuan untuk mengetahui perkembangan media yang telah dikembangkan. Rekapitulasi hasil uji coba lapangan utama pada tabel 8 . Hasil penilaian guru melalui uji coba lapangan utama ini diperoleh rata-rata sebesar 82,38\% dalam kriteria sangat baik. Hal ini dapat diinterpretasikan bahwa buku panduan identifikasi awal anak berkebutuhan khusus sangat layak digunakan.

\section{Tabel 8. Hasil Uji Coba Lapangan Utama}

\begin{tabular}{clcc}
\hline No. & \multicolumn{1}{c}{ Aspek } & Skor Perolehan & Skor Maksimal \\
\hline 1. & Materi Panduan & 200 & 240 \\
2. & Bahasa dan Struktur Kalimat & 144 & 180 \\
3. & Tampilan Buku Panduan & 348 & 420 \\
& Total & 692 & 840 \\
& Rata-rata (\%) & \multicolumn{2}{c}{82,38} \\
\multicolumn{2}{c}{ Interpretasi } & \multicolumn{2}{c}{ Sangat Baik } \\
\hline
\end{tabular}




\section{Pembahasan}

Pada tahap ketiga model pengembangan Rowentree ini (Tahap Penulisan dan Penyuntingan), peneliti melakukan kegiatan pertama dalam tahap ini adalah memulai membuat draft satu dengan mengacu pada garis-garis besar ide panduan yang telah dirancang sebelumnya. Setelah draft 1 isi dan materi tersusun secara urut dan sistematis, peneliti melanjutkan kegiatan dengan membuat draft sampul depan yang menggambarkan secara garis besar isi panduan didalamnya. Sampul depan terfokus pada ilustrasi gambar empat orang anak beserta ilustrasi gambar awan yang berisi tulisan berdasarkan pertanyaanpertanyaan dan kekhawatiran para guru. Sampul depan panduan untuk draft satu dapat dilihat pada Gambar 2 dan 3.

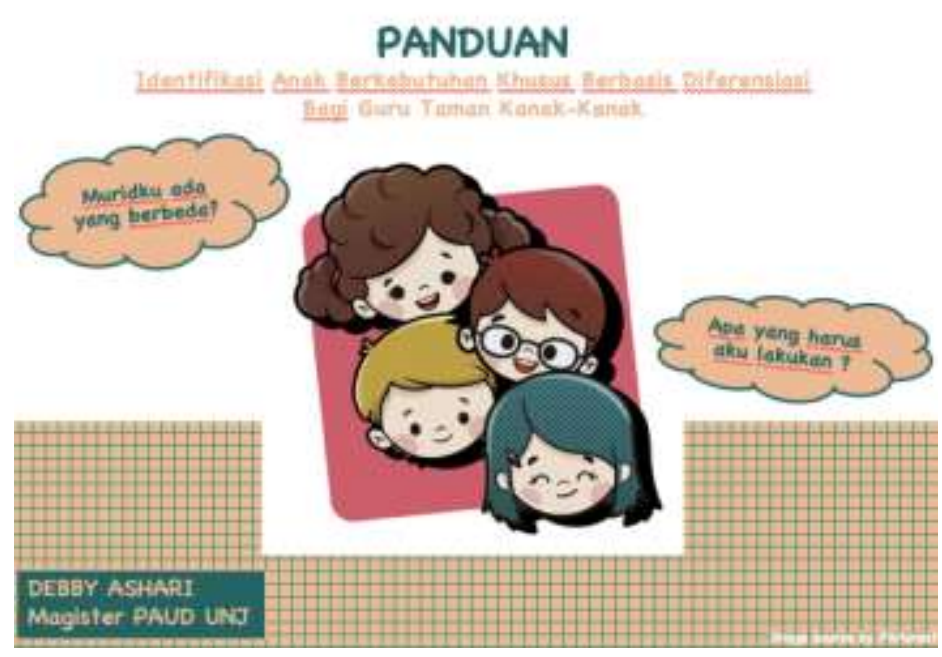

Gambar 2. Draft 1 Sampul Depan Panduan Identifikasi Awal ABK

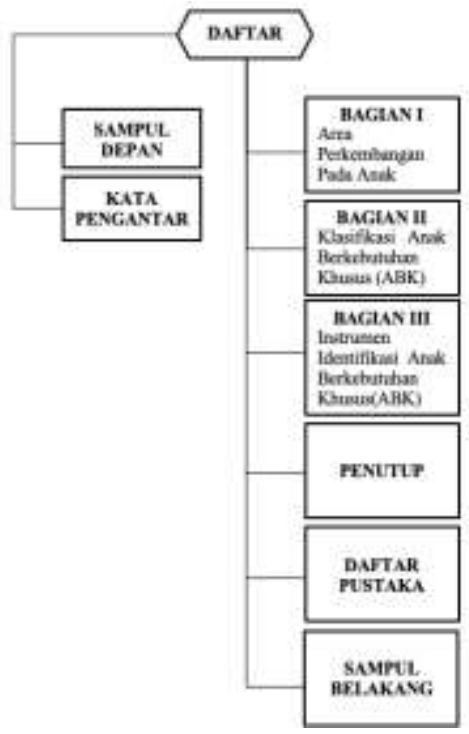

Gambar 3. Draft 1 Panduan Identifikasi Awal ABK

Pentingnya sampul depan buku panduan ini juga diungkapkan oleh Pinandhita \& Christiana (2016) pada hasil penelitiannya yang mengungkapkan bahwa sampul depan buku panduan ini diartikan sebagai sarana pemberian informasi dalam pelayanan bagi penggunanya yang berisi materi dan evaluasi yang dikemas secara praktis dan nampak teoritis isinya.

Kegiatan peneliti dilanjutkan dengan melengkapi dan menyunting draft satu panduan ini dengan menyusun materi sesuai dengan sistematika penulisan sebelumnya dan disesuaikan dengan ukuran kertas serta tata letak penulisan agar tidak mengganggu saat membaca panduan ini. Setelah proses ini maka draft satu melangkah maju pada kegiatan menguji kelayakan produk oleh para pakar, uji coba one to one dan uji coba kelompok kecil untuk memperbaiki produk panduan ini menjadi sebuah buku panduan yang teruji kelayakan dan dapat digunakan di lapangan utama. Hal ini sejalan juga dengan hasil penelitian yang dilakukan oleh Kurniazuhroh \& Adhe, K. (2019) yang mengungkapkan bahwa tahap uji coba di lapangan merupakan tahap yang sangat penting untuk menghasilkan buku panduan yang teruji dan dapat diterima di lapangan. Buku panduan yang teruji akan memberikan manfaat atau kegunaan bagi penggunanya dalam hal ini yaitu guru dalam melaksanaan kegiatan pembelajaran.

Pada tahap hasil uji kelayakan pakar kedua yang dilakukan oleh ahli media didapatkan hasil pada kategori baik. Hasil uji kelayakan tersebut bisa dilihat pada Tabel 9. Berdasarkan Tabel 9 hasil penilaian ahli media terhadap buku panduan identifikasi anak berkebutuhan khusus diperoleh skor rata-rata penilaian pertama dalam bentuk prosentase adalah $60,41 \%$. Hasil dari penilaian ini berada dalam kriteria interpretasi skor $51 \%-75 \%$ dinilai baik dengan makna yang menyatakan bahwa buku panduan identifikasi awal anak 
berkebutuhan khusus layak dan dapat digunakan sebagai media. Berikut hasil revisi telaah ahli media sebagaimana terlihat pada tabel 10.

Tabel 9. Hasil Uji Kelayakan Pakar Kedua (Ahli Media)

\begin{tabular}{clc}
\hline No. & \multicolumn{1}{c}{ Aspek } & Penilaian II (\%) \\
\hline 1. & Tampilan & 62,50 \\
2. & Teks Tulisan & 68,75 \\
3. & Ilustrasi Gambar & 50,00 \\
& Rata-rata (\%) & 60,41 \\
& Kategori & Baik \\
\hline
\end{tabular}

Tabel 10. Hasil Revisi Telaah Ahli Media

\begin{tabular}{|c|c|c|c|}
\hline No. & Ahli & Saran Masukan & Revisi \\
\hline 1. & Ahli Media & $\begin{array}{l}\text { a. Materi dibuat lebih banyak cara } \\
\text { daripada teorinya. }\end{array}$ & $\begin{array}{l}\text { Materi telah dibuat lebih praktis, } \\
\text { banyak memberikan cara/ tips, serta } \\
\text { lebih mudah digunakan oleh guru. }\end{array}$ \\
\hline & & $\begin{array}{l}\text { b. Perhatikan prinsip grafis, } \\
\text { terutama margin. Perlu ilustrasi } \\
\text { dan gambar agar tidak monoton. }\end{array}$ & $\begin{array}{l}\text { Telah memperbanyak ilustrasi dan } \\
\text { memperbaiki grafis. }\end{array}$ \\
\hline
\end{tabular}

Ahli materi yang menguji kelayakan atau memvalidasi draft satu buku panduan identifikasi awal anak berkebutuhan khusus adalah Riana Bagaskorowati, S.Pd., M.Si., Ph.D selaku dosen Pendidikan Khusus Universitas Negeri Jakarta. Berdasarkan instrumen penilaian tersebut data kemudian diolah dan diambil persentase. Berdasarkan hasil perhitungan penilaian dari ahli materi diperoleh nilai (Tabel 11).

Tabel 11. Hasil Uji Kelayakan Pakar Kedua (Ahli Materi)

\begin{tabular}{clc}
\hline No. & \multicolumn{1}{c}{ Aspek } & Penilaian II (\%) \\
\hline 1. & Tujuan Penyusunan Panduan & 87,50 \\
2. & Materi & 81,25 \\
3. & Bahasa & 90,00 \\
& Rata-rata & 86,25 \\
& Kategori & Sangat Baik \\
\hline
\end{tabular}

Berdasarkan tabel hasil penilaian ahli materi terhadap buku panduan identifikasi anak berkebutuhan khusus diperoleh skor rata-rata penilaian pertama dalam bentuk prosentase adalah $86,25 \%$. Hasil dari penilaian ini berada dalam kriteria interpretasi skor $76 \%$ - 100\% dinilai sangat baik dengan makna yang menyatakan bahwa buku panduan identifikasi awal anak berkebutuhan khusus layak dan dapat digunakan sebagai media.

\section{Tabel 12. Hasil Revisi Telaah Ahli Materi}

\begin{tabular}{|c|c|c|c|}
\hline No. & Ahli & Saran Masukan & Revisi \\
\hline 1. & Ahli Materi & $\begin{array}{l}\text { a. Gunakan referensi } \\
\text { yang up to date. }\end{array}$ & $\begin{array}{l}\text { Materi telah dibuat dengan menggunakan sumber- } \\
\text { sumber yang up to date (terkini). }\end{array}$ \\
\hline
\end{tabular}

Ahli intrumen yang menguji kelayakan atau memvalidasi draft satu buku panduan identifikasi awal anak berkebutuhan khusus adalah Dr. Wuryani, M.Pd. selaku dosen Pendidikan Khusus Universitas Negeri Jakarta. Berdasarkan instrumen penilaian tersebut data kemudian diolah dan diambil persentase. Berdasarkan hasil perhitungan penilaian dari ahli instrumen diperoleh nilai (Tabel 13). 
Tabel 13. Hasil Uji Kelayakan Pakar Kedua (Ahli Instrumen)

\begin{tabular}{clc}
\hline No. & \multicolumn{1}{c}{ Aspek } & Penilaian II (\%) \\
\hline 1. & Bahasa & 81,25 \\
2. & Konstruksi & 83,33 \\
3. & Materi & 83,33 \\
& Rata-rata & 82,63 \\
& Kategori & Sangat Baik \\
\hline
\end{tabular}

Berdasarkan tabel hasil penilaian ahli instrumen terhadap buku panduan identifikasi anak berkebutuhan khusus diperoleh skor rata-rata penilaian pertama dalam bentuk prosentase adalah $82,63 \%$. Hasil dari penilaian ini berada dalam kriteria interpretasi skor $75 \%$ $100 \%$ dinilai sangat baik dengan makna yang menyatakan bahwa buku panduan identifikasi awal anak berkebutuhan khusus layak dan dapat digunakan sebagai media.

Tabel 14. Hasil Revisi Telaah Ahli Instrumen

\begin{tabular}{cccl}
\hline No. & Ahli & \multicolumn{1}{c}{ Saran Masukan } & \multicolumn{1}{c}{ Revisi } \\
\hline 1. & Ahli & Buat instrumen yang lebih terperinci & Kalimat dalam instrumen sudah \\
& Instrumen & dan lengkapi semua kekhususannya. & $\begin{array}{l}\text { diperbaiki menjadi lebih jelas dan } \\
\text { terperinci serta sudah dilengkapi } \\
\text { dengan seluruh kekhususan. }\end{array}$ \\
\hline
\end{tabular}

Berdasarkan tabel hasil penilaian yang kedua dari para ahli media, materi serta instrumen terhadap panduan identifikasi dini anak berkebutuhan khusus diperoleh skor ratarata dari ahli media sebesar $60,41 \%$. Skor rata-rata dari ahli materi sebesar $86,25 \%$, dan skor rata-rata dari ahli instrumen sebesar $82,63 \%$. Hasil dari keempat penilaian dari para ahli media dan materi diperoleh skor rata-rata sebesar $76,43 \%$. Skor ini berada dalam kriteria interpretasi skor $76 \%-100 \%$ dinilai sangat baik dengan makna yang menyatakan bahwa telah sangat layak dan dapat digunakan sebagai media.

Dari hasil penilaian guru melalui uji coba one to one diperoleh rata- rata $73,80 \%$. Hasil penilaian ini masuk dalam kriteria baik. Hal ini dapat diinterpretasikan bahwa buku panduan identifikasi awal anak berkebutuhan khusus telah layak digunakan. Tabel 15 adalah revisi hasi uji coba one to one:

Tabel 15. Revisi Draft 1 Hasil Uji Coba One to One

\begin{tabular}{cll}
\hline No. & \multicolumn{1}{c}{ Saran dan Masukan } & \multicolumn{1}{c}{ Revisi } \\
\hline 1. & Ilustrasi gambar dapat ditambahkan agar lebih hidup. & Telah direvisi sesuai saran peserta. \\
2. & Memberikan warna solid agar lebih jelas tulisannya. & Telah direvisi sesuai saran peserta. \\
3. & Penggunaan bahasa lebih disederhanakan. & Telah direvisi sesuai saran peserta. \\
\hline
\end{tabular}

Dari hasil penilaian guru melalui ujicoba kelompok kecil diperoleh rata- rata $76,42 \%$. Hasil penilaian ini masuk dalam kriteria sangat baik. Hal ini dapat diinterpretasikan bahwa buku panduan identifikasi awal anak berkebutuhan khusus sangat layak digunakan.

Tabel 16. Revisi Draft 1 Hasil Uji Coba Kelompok Kecil

\begin{tabular}{cll}
\hline No. & \multicolumn{1}{c}{ Saran dan Masukan } & Revisi \\
\hline 1. & Ilustrasi gambar dapat ditambahkan kembali & Telah direvisi sesuai saran peserta. \\
2. & Lebih diperbanyak saran/ masukan untuk guru & Telah direvisi sesuai saran peserta. \\
3. & Bahasa yang digunakan lebih praktis lagi & Telah direvisi sesuai saran peserta. \\
\hline
\end{tabular}


Berdasarkan langkah-langkah kegiatan dengan model Rowentree yang telah dilakukan dalam memproduksi sebuah buku panduan cetak dan hasil saran masukan ujicoba kelompok kecil, maka didapat hasil akhir dari tahap pengembangan model ADDIE yaitu sebuah draft dua yang ditampilkan pada Tabel 17.

Tabel 17. Hasil Revisi Draft II Buku Panduan

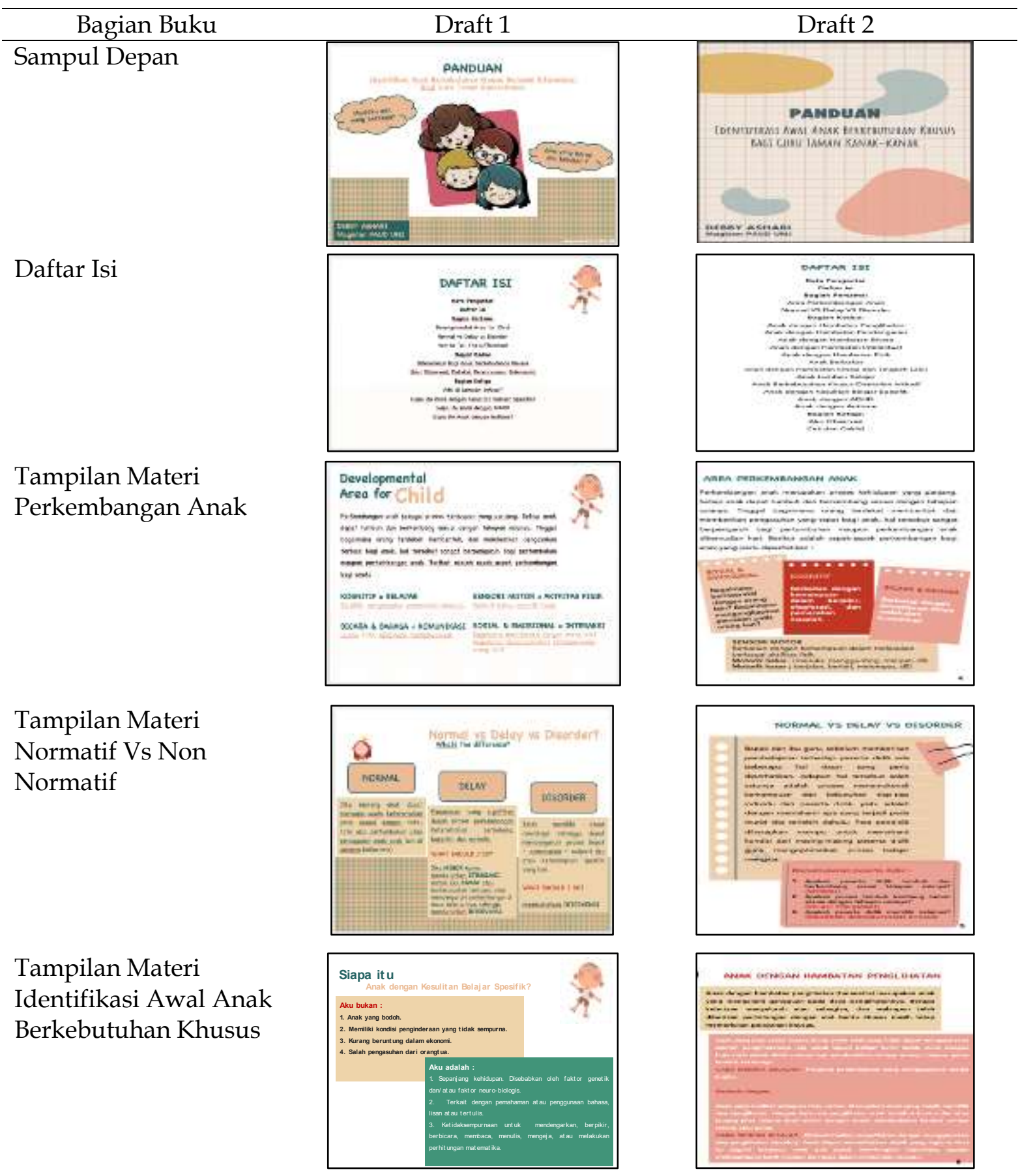




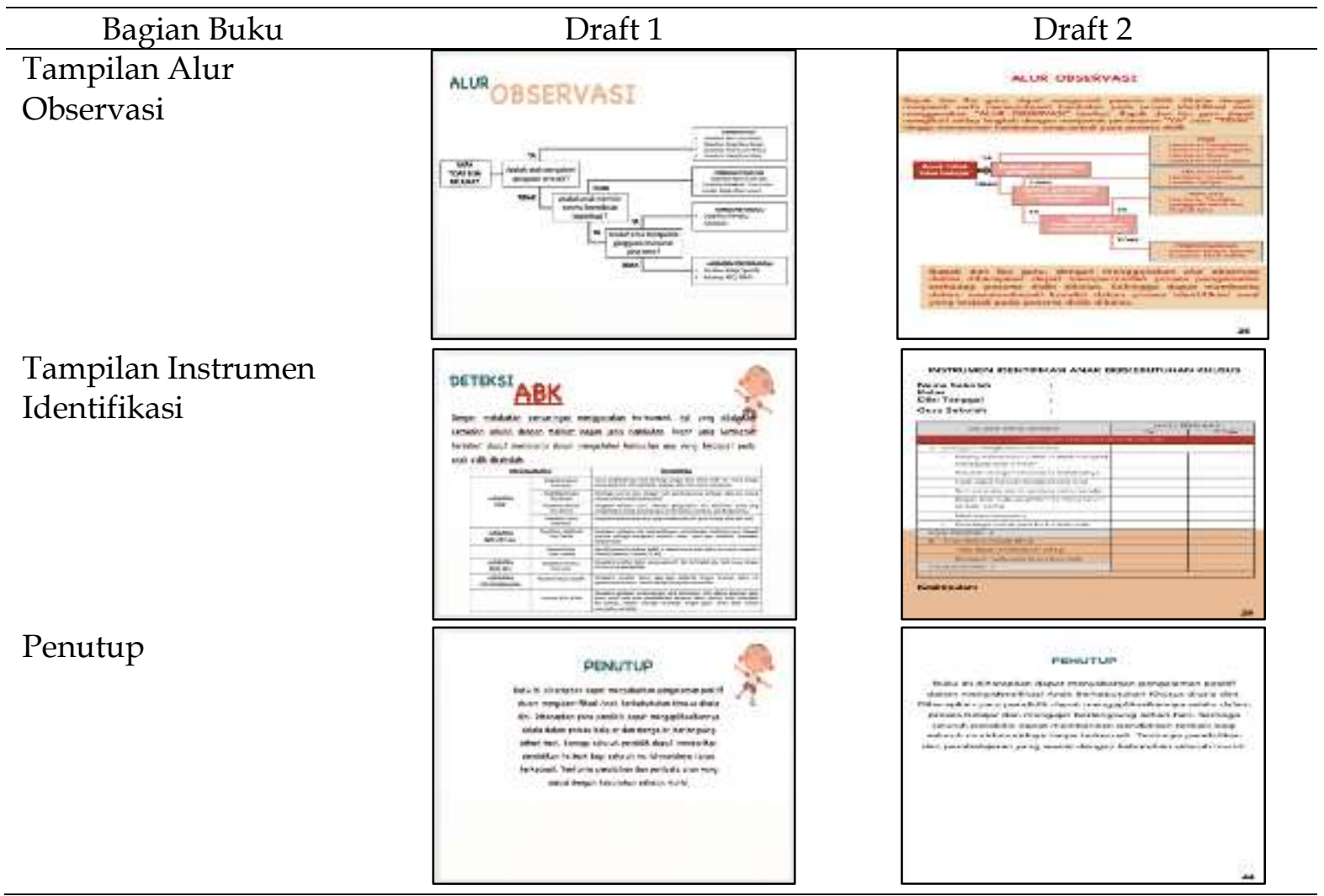

Semua tahapan penelitian dan pengembangan yang telah menghasilkan produk berupa buku panduan ini sejalan dengan tahapan umum yang dilakukan oleh peneliti-peneliti sebelumnya (Pinandhita \& Christiana, 2016; Kurniazuhroh \& Adhe, K., 2019). Namun terletak perbedaan dan kebaruan dengan tahapan penelitian yang peneliti lakukan. Tahapannya mengadopsi model ADDIE dengan tahapan Rowantree yang belum pernah dilakukan. Berbeda dengan tahapan yang dilakukan oleh Kurniazuhroh \& Adhe, K. (2019) dimana dalam penelitiannya menggunakan tahapan ADDIE saja. Sedangkan Rosiyanah et al. (2020) melakukan uji coba pada buku panduan yang dikembangkannya.

Lain halnya dengan hasil penelitian yang dilakukan oleh Suryaningrum et al. (2016) yang mengungkapkan bahwa pengembangan model deteksi dini anak berkebutuhan khusus pada tingkat anak usia dini lebih efektif dengan mengimplementasikan model PATH (Problem-Analysis-Test (Model)- Help) dengan perincian sebagai berikut: 1) Tahap Problem, peneliti mengidentifikasi dan mendefinisikan problem; 2) Tahap Analisis, peneliti menggunakan data yang diperoleh pada tahap 1 dan dianalisis dengan teori yang ada, selanjutnya disusun model awal yang akan diujicobakan; 3) Tahap Tes Model, peneliti melakukan uji coba terhadap model, evaluasi, dan revisi model; dan 4) Tahap Help adalah mengimplementasikan model untuk melakukan intervensi, sebagai sebuah intervensi, metode ini menghendaki penelitian tidak berhenti sampai pada tahap validasi model, namun memberdayakan pihak-pihak yang berkepentingan untuk dapat menggunakan model tersebut secara mandiri dan berkelanjutan.

\section{SIMPULAN}

Kebutuhan dalam panduan identifikasi awal anak berkebutuhan khusus ini dapat mengakomodasi kebutuhan guru dalam pengembangan kompetensi maupun pengetahuannya dalam mengidentifikasi anak berkebutuhan khusus di lembaga pendidikan masing-masing. Panduan identifikasi awal anak berkebutuhan khusus ini dinilai layak oleh ahli materi dari aspek tujuan penyusunan, kesesuaian materi, dan kesesuaian bahasa dengan kategori sangat baik. Panduan ini pun juga dinilai layak oleh ahli media dengan aspek penilaian pada tampilan, teks tulisan, dan ilustrasi gambar berada dalam kategori baik. 
DOI: $10.31004 /$ obsesi.v6i2.1677

Panduan ini pun dikatakan layak oleh ahli instrumen dalam beberapa aspek penilaian yaitu kesesuaian bahasa, konstruksi, dan materi dengan kategori sangat baik.

\section{UCAPAN TERIMA KASIH}

Dengan segala hormat dan kerendahan hati, peneliti memanjatkan puji syukur kehadirat Allah SWT atas segala rahmat dan karunia-Nya, sehingga peneliti dapat menyelesaikan penulisan artikel ilmiah ini. Dalam pembuatan artikel ilmiah ini, peneliti mendapatkan arahan, bantuan, dan bimbingan yang sangat berharga dari berbagai pihak. Pada kesempatan ini, peneliti mengucapkan terima kasih yang sebesar-besarnya kepada teman-teman seperjuangan di program pascasarjana Universitas Negeri Jakarta, para orangtua dan guru-guru di Taman Kanak-kanak, serta tim pengelola dan tim reviewer artikel jurnal yang telah meluangkan waktu dan kesempatannya untuk memberikan kesempatan dan arahan sehingga artikel ini dapat dipublikasikan.

\section{DAFTAR PUSTAKA}

Anggadewi, B., E., T., \& Evanjeli, L., A. (2019). Identification and Assessment of Children with Special Needs in Inclusive Elementary School. Advances in Social Science, Education and Humanities Research, 388(3), 128-131.

Hafidh, F., Kurniawan, M. Y., \& Mirnawati, M. (2020). PKM Aplikasi Asesmen Anak Berkebutuhan Khusus di Sekolah Luar Biasa dan Inklusi Kabupaten Banjar. GERVASI: $\begin{array}{llll}\text { Jurnal Pengabdian } & \text { Kepada }\end{array}$ https://doi.org/10.31571/gervasi.v3i2.1353

Hussain Alom Assistant Professor of Education, J. (2020). Early Identification Mechanisms for Special Needs Children: A Comprehensive Analysis. In Mukt Shabd Journal: Vol. IX (Issue V).

Jaya, I., Soendjojo, R. P., Pujiastuti, H., \& Wahyuni, M. (2018). Prosedur Operasi Standar Pendidikan Anak Usia Dini Inklusif (Issue 021). Kementerian Pendidikan dan Kebudayaan Direktorat Jenderal Pendidikan Anak Usia Dini dan Pendidikan Masyarakat Direktorat Pembinaan Pendidikan Anak Usia Dini.

Kurniazuhroh, F., \& Adhe, K. R. (2019). Pengembangan Buku Panduan Menjahit Bagi Guru Taman Kanak-Kanak di Sidoarjo. Jurnal PAUD Teratai, 8(1), 1-6. https://jurnalmahasiswa.unesa.ac.id/index.php/paud-teratai/article/view/28504

Maman, Baharun, H., Witarsa, R., Ainin, D. T., Hodaili, Z., Mushorfan, \& Wiranata, M. A. (2021). Google Classroom as a Distance Learning Tool during a Pandemic. Journal of Physics: Conference Series, 1899(1), 1-6. https://doi.org/10.1088/1742$\underline{6596 / 1899 / 1 / 012176}$

Mensah, F. A., \& Badu-Shayar, J. (2016). Identification of special educational needs for early childhood inclusive education in Ghana. Journal of Education and Practice, 7(11), 1-8. www.iiste.org

Moeschler, J. B., Shevell, M., Saul, R. A., Chen, E., Freedenberg, D. L., Hamid, R., Jones, M. C., Stoler, J. M., \& Tarini, B. A. (2014). Comprehensive evaluation of the child with intellectual disability or global developmental delays. Pediatrics, 134(3), e903-e918. https://doi.org/10.1542/peds.2014-1839

Musanib, M. (2013). Meningkatkan Keterampilan Identifikasi Anak Berkebutuhan Khusus Bagi Mahasiswa Program Studi PGPAUD FKIP Universitas Tadulako [Improve Child Identification Skills Special Needs For Students of Early Childhood Education Program Tadulako University]. Tri Sentra Jurnal Ilmu Pendidikan, 2(4), 20-30.

Pinandhita, F., \& Christiana, R. (2016). Pengembangan Buku Panduan Berbasis Problem Solving dalam Meminimalisir Kekhawatiran pada Kelas Speaking Mahasiswa Program Studi Bahasa Inggris IKIP PGRI MADIUN. Jurnal Kependidikan, 15(1), 11-20. 
Pratiwi, J., C. (2015). Sekolah Inklusi untuk Anak Berkebutuhan Khusus: Tanggapan terhadap Tantangan Kedepannya. Prosiding Seminar Nasional Pendidikan "Meretas Sukses Publikasi Ilmiah Bidang Pendidikan Jurnal Bereputasi," November, 237-242.

Rapisa, D. R. (2018). Kemampuan guru dalam melakukan identifikasi anak berkebutuhan khusus. PEDAGOGIA, 16(1), 16. https:// doi.org/10.17509/pdgia.v16i1.10731

Rosiyanah, R., Yufiarti, Y., \& Meilani, S. M. (2020). Pengembangan Media Stimulasi Sensori Anak Usia 4-6 Tahun Berbasis Aktivitas Bermain Tujuh Indera. Jurnal Obsesi : Jurnal Pendidikan Anak Usia Dini, 5(1), 941-956. https://doi.org/10.31004/obsesi.v5i1.758

Roza, A., \& Rifma. (2000). Perencanaan Pembelajaran Anak Berkebutuhan Khusus dalam Majamen Sekolah Inklusif. Jurnal Kajian Pendidikan Dasar (JKPD), 5(1), 61-69. https://journal.unismuh.ac.id/index.php/jkpd/article/view/3085

Suryaningrum, C., Ingarianti, T., M., \& Anwar, Z. (2016). Pengembangan Model Deteksi Dini Anak Berkebutuhan Khusus (ABK) pada Tingkat Pendidikan Anak Usia Dini (PAUD) di Kota Malang. Jurnal Ilmiah Psikologi Terapan, 04(01), 62-74.

Witarsa, R., \& Dista, D. X. (2019). Analisis Jawaban Siswa Usia 6 sampai 8 tahun terhadap Pembelajaran Sains Kreatif. Jurnal Obsesi : Jurnal Pendidikan Anak Usia Dini, 4(1), 58. https://doi.org/10.31004/obsesi.v4i1.288 